\title{
都市鉄道整備期の自動車分担率に着目した 駅周辺地域における交通環境負荷の経年分析
}

\author{
津村 優磨 1 松中 亮治 $2 \cdot$ 大庭 哲治 3 -中川 大4 \\ 1学生会員 京都大学大学院工学研究科（一 615-8540 京都市西京区京都大学桂） \\ E-mail: ytsumura@urban.kuciv.kyoto-u.ac.jp \\ 2正会員 京都大学准教授 大学院工学研究科（率615-8540 京都市西京区京都大学桂) \\ E-mail:matsu@urban.kuciv.kyoto-u.ac.jp \\ 3 正会員 京都大学助教 大学院工学研究科（广615-8540 京都市西京区京都大学桂） \\ E-mail: tetsu@urban.kuciv.kyoto-u.ac.jp \\ 4正会員 京都大学教授 大学院工学研究科（干615-8540 京都市西京区京都大学桂） \\ E-mail: nakagawa@urban.kuciv.kyoto-u.ac.jp
}

\begin{abstract}
本研究は, 東京都市圈, 中京都市圈, 京阪神都市圈において近年整備された都市鉄道駅について, 都市 鉄道整備期における自動車分担率に着目した上で, 駅周辺地域における交通環境負荷を経年的に分析した。

その結果，整備期における自動車分担率が低い駅ほど，都市鉄道駅整備による交通環境負荷の抑制傾向 が強まることを統計的に明らかにした。逆に，モータリゼーションの進展に伴って発展した自動車依存型 の地域においては, 都市鉄道駅が整備されたにも関わらず, 交通環境負荷の増加傾向が経年的に強まるこ とを示した.ただし既に自動車分担率の高い地域においても, 開発率が高い既成都市域では, 列車運行本 数の多い都市鉄道駅を整備することで，一定の交通環境負荷の抑制傾向が得られることを示した.
\end{abstract}

Key Words : timing of urban railway development, environmental impact of transport, modal share of private cars

\section{1. はじめに}

\section{(1) 背景と目的}

モータリゼーションは，人々のライフスタイルを大き く転換させ，都市機能の構造的変化を伴って，加速度的 に進展する性質を持つ。さらに自動車は公共交通にない 機動性，随意性を有しており，交通利便性の低い郊外地 域に都市空間を面的に拡大させる.この自動車交通によ り形成される低密度な都市構造は，高密度で線的な都市 構造に適した公共交通の衰退を招き，自動車保有率をよ り一層上昇させる. 高まる自動車交通の需要に追従する 形で道路インフラ整備の推進，都市鉄道整備の遅れによ って，このスパイラルはより一層加速され，自動車依存 型都市の形成が促進され，副次的に交通環境負荷の増加 が進さ.この一連のプロセスを, 加藤・林 1)はモータリ ゼーション・アクセラレーションと呼称した. このよう なスパイラル構造により，モータリゼーションは不可逆 反応であるとも指摘されている ${ }^{2)}$. つまり都市がモータ リゼーションの進展を経て, 自動車依存型の都市発展に
おける「臨界点」を越えた後においては，従来の公共交 通依存型都市への再転換は容易ではないと考えられる ${ }^{3)}$. 北村 4)は，この再転換が困難となる時点を Point of No Return と呼称した.

このことから，モータリゼーション・アクセラレーシ ヨンを抑制するために, モータリゼーション進展前の段 階における都市鉄道の早期整備が望ましいと考えられる. この都市鉄道整備期の最適化については，特に都市鉄道 整備の遅れが顕著であるアジア途上国の大都市圏を対象 に研究が進められてきた. Acharya $a^{5}$ は公共交通中心の都 市発展に関するシナリオを複数想定し，モータリゼーシ ヨンが進展する中で，その達成の臨界点を Critical Stage と呼称し，持続可能な低炭素社会の実現に向けて，都市 鉄道等の新たな大量輸送手段の整備期を適切に見極める ことの必要性を主張した.さらにMorichiðは，東京都市 圏をモデルケースとして，都市鉄道整備のタイミングの 最適化を主張した。しかしいずれの研究においても，今 後の交通システムの低炭素化が求められている中, 都市 鉄道の早期整備による交通環境負荷抑制効果についての 
知見は示されていない. また Acharya and Morichi ${ }^{7} は$ ，東 アジアの大都市を対象に都市鉄道整備期と都市構造・収 入分布との関連性を明らかにした上で，収入分布と人口 分布により都市鉄道整備期を評価する手法を提唱した.

Koizumi et al..$^{8}$ は，アジア途上国を含む世界の大都市にお ける都市鉄道整備期と GDP の関連性を明らかにした。

しかし前述のモータリゼーション・アクセラレーション のメカニズムを踏まえると，モータリゼーションの進展 度(自動車分担率)を考慮した上で, 都市鉄道整備期を評 価する必要性があると考えられる。

都市鉄道と交通行動・交通環境負荷の関連性に着目し た研究については, 都市・都市圈単位といったマクロス ケールでの研究, 駅勢圈(駅周辺 $1 \mathrm{~km}) \cdot$ 小地域・町丁目と いったミクロスケールでの研究に大きく二分される.

マクロスケールの研究としては, 世界中の都市を対象 に人口密度と交通起源エネルギー消費量の関連性を明ら かにしたNewman and Kenworthy9)の研究をはじめ,

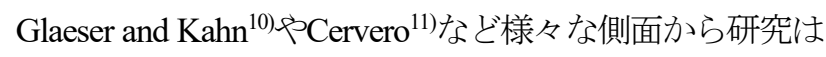
進められてきた。谷口ら ${ }^{12}$ は, 全国PT調査のマスターデ ータを用いて, 都市構造が自動車 $\mathrm{CO}_{2}$ 排出量に及ぼす影 響は日本の市区町村においても存在することを示した.

松橋ら $\left.{ }^{13}\right)$ は全国の市区町村を対象に, OD登録地別・目的 地別に $\mathrm{CO}_{2}$ 排出量の推計方法を探索し，市区町村別の特 性によって排出量の数值の傾向に差異が見られることを 示した. その後, 谷口ら ${ }^{14)}$ は, 自動車 $\mathrm{CO}_{2}$ 排出量と都市 の空間的パターンや公共交通の整備状況との関連性につ いても明らかにした. さらに国際比較を主眼とした研究 として, 世界のメガシティを対象に人口密度と自動車利 用との関連性を明らかにした鈴木・室町 ${ }^{15}$ の研究，都市 単位で世界の先進国における都市鉄道の整備状況が都市 構造や機関分担率に及ぼす影響を明らかにした Kenworthy ${ }^{16}$ の研究, 世界の先進国および途上国を対象に, 人口密度と自動車 $\mathrm{CO}_{2}$ 排出量および交通行動との関連性 を明らかにしたChoi et al. ${ }^{17)}$ の研究などが挙げられる.し かしこれらの研究では, 自動車 $\mathrm{CO}_{2}$ 排出量のみを考慮し た研究も多く，また都市鉄道整備期と交通環境負荷の関 連性は考慮されていない。

また都市鉄道整備期と交通環境負荷の関連性を探求し た研究として, 島田ら゙は, マクロデータを用いて自動 車依存型都市からの非依存型都市一の転換は困難である という仮説を検証することで，人口集積が進まない非都 市化地域においては, 都市鉄道整備が自動車保有率の減 少に及ぼす影響は小さくなることを示した. また栂ら ${ }^{18)}$, 中村ら ${ }^{19), 20)}$ と Ito et al. $\left.{ }^{21}\right)$ は, 都市鉄道の早期整備による自 動車保有率・交通環境負荷の抑制効果を, マクロモデル の時系列予測により明らかにした. しかしこれらの研究 では，実証データにより都市鉄道整備期と交通環境負荷 の傾向との関連性は明らかにされてない.また都市鉄道
整備による沿線住民の交通行動の変化は, 駅勢圈単位で 発生し得るミクロな現象であり, その交通行動の変化に より生じる交通環境負荷の経年的傾向をより詳細な分析 単位で明らかにする必要性があると考えられる.

一方でミクロスケールでの研究として, 北村ら 22)は京 阪神 PT 調查結果を用いて, 土地利用政策の有効性を模 索した. 中道ら ${ }^{23,24)}$ は, 自動車利用に関する個人の属性 と比較して, 居住地の地区特性が交通環境負荷に及ぼす 影響が小さいことを明らかにした。森川ら ${ }^{25}$ は, モータ リゼーション以降に開発された小地域の自動車 $\mathrm{CO}_{2}$ 排出 量は高い傾向にあることを明らかにした。 その他，鉄道 整備が人口密度と自動車利用の双方に影響を与える可能 性を明らかにした鈴木・室町 ${ }^{26 の}$ の研究, 都市構造の変化 が交通行動に及ぼす影響を明らかにした Mendiola et al. ${ }^{27)}$ の研究，土地利用と交通行動の関連性を明らかにした Travisi et al. ${ }^{28) の}$ の研究が挙げられる. しかし都市鉄道整備 期と交通環境負荷の関連性を考慮した研究は見られない

以上の既往研究においては, 全ての日常交通手段から 排出される交通環境負荷を考慮し, 駅勢圈というミクロ な分析単位により，都市鉄道整備期と交通環境負荷の関 連性は明らかにされていないことが分かる.さらに都市 鉄道整備期をモータリゼーションの進展度(自動車分担 率)により評価された研究は見られない.

そこで本研究は, 既に高度経済成長による急速なモー タリゼーションを経験し，かつ都市鉄道整備が順次進め られてきた日本の東京都市圈, 中京都市圈, 京阪神都市 圈の近年整備された都市鉄道駅の周辺地域において，交 通機関分担率やトリップ特性を反映した指標である交通 環境負荷の経年的傾向と都市鉄道整備期の自動車分担率 との関連性を明らかにすることを目的とする.

本研究で得られる成果は, 急速なモータリゼーション に対して, 都市鉄道整備の遅れが指摘されている途上国 の大都市圈に対して, 有効な知見を提供することができ ると考える.

\section{(2) 本研究の特徵}

以上を踏まえ, 本研究の特徵を以下に挙げる.

- 全ての日常交通手段から排出される交通環境負 荷を経年的に考慮する点

- 都市鉄道整備期における駅周辺地域の自動車分 担率に着目寸る点

- 詳細な分析単位(駅勢圈 : 駅周辺 $1 \mathrm{~km})$ で整備後の 交通環境負荷の経年変化を分析する点

\section{2. データベースの構築}

本章においては，分析に用いるデータベースを構築す 
るために，対象新駅の定義を示した後に，対象新駅の駅 勢圈における自動車分担率，整備期における開発率，列 車運行本数を集計する. その後, 各都市圈パーソントリ ップ調查(以下，PT調查)を用いて，対象新駅の周辺地域 における交通環境負荷を推計する.

\section{（1）対象新駅の定義}

本研究では, 都市鉄道の早期整備によりモータリゼー ションが抑制されたと考えられる地域と, 晚期整備によ るモータリゼーションの抑制が弱まったと考えられる地 域が混在する, 日本の大都市圏である東京都市圏, 中京 都市圈, 京阪神都市圈を対象都市圈とする. なお各都市 圈の領域は, 1988年実施の第3回東京都市圈PT調查, 1991 年実施の第3回中京都市圈PT調査, 1990年実施の第3回京 阪神都市圈PT調查の調查対象域とする.

上記の対象都市圈内において，都市間高速鉄道，無軌 条電車および鋼索線を除く, 専用軌道を有寸る全ての公 共交通機関を「都市鉄道」と定義する．本研究では，既 設駅の影響を除外した上で，日常利用を前提とした路線 の新駅を対象とするため, 以下の条件を満たす都市鉄道 の計344駅を対象新駅とする.

・ 1970 年から 1999 年の期間に新規整備された都市鉄 道の常設駅であり, 平日・休日ともに発着列車が設 定されていること.

- 1970 年代・1980 年代・1980 年代に整備された都市 鉄道駅について, 1969 年末・1979 年末・1989 年末 のそれぞれの時点において駅周辺 $1 \mathrm{~km}$ 圈内に既存 の他都市鉄道駅が存在していないこと.

- 駅勢圈内において, 整備年代における国勢調査の利 用交通手段が集計されていること.

・空港敷地に併設されていないこと.

\section{（2）駅勢圏自動車分担率の算出}

対象新駅の整備期における自動車利用実態を把握する ために, 国勢調查の通勤・通学手段の項目を利用し, 1970 年, 1980年, 1990年の計3年次について, 各駅勢圏におけ る自動車分担率を算出する．またその経年変化に着目す るために, 2000年, 2010 年の 2 年次における值も算出寸る.

初めに，国勢調查に関寸る地域メッシュデータ29)を用 いて, 駅勢圈自動車分担率を算出する. なお，データの 利用可能性の都合上，1970年，1980年および1990年のデ ータに関しては3次メッシュ, 2000年, 2010年のデータに 関しては4次メッシュをそれぞれ用いた.このメッシュデ 一タを用いて, 各メッシュ内の通勤・通学者数の密度は 一定であると仮定し, 駅勢圈内と駅勢圈外の面積比から, 利用交通手段別に集計された15歳以上の通勤・通学者数 を按分する. さらに，駅勢圈内における住民の利用交通 手段として「自家用車」を選択した人数の割合を求める
表-1 可住地および都市的土地利用の定義

\begin{tabular}{|c|c|c|c|c|c|}
\hline No. & 1976 年 & 1987 年 & 1997 年 & 可住地 & 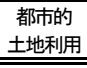 \\
\hline 1 & 田 & 田 & 田 & $\circ$ & - \\
\hline 2 & 畑 & 畑 & \multirow{3}{*}{ その他農用地 } & $\circ$ & - \\
\hline 3 & 果樹園 & 果樹園 & & $\circ$ & - \\
\hline 4 & その他の樹木畑 & その他の樹木畑 & & $\circ$ & - \\
\hline 5 & 森林 & 森林 & 森林 & - & - \\
\hline 6 & 荒地 & 荒地 & 荒地 & $\circ$ & - \\
\hline 7 & 建物用地 A & \multirow{2}{*}{ 建物用地 } & \multirow{2}{*}{ 建物用地 } & $\circ$ & $\circ$ \\
\hline 8 & 建物用地 B & & & $\circ$ & $\circ$ \\
\hline 9 & 幹線交通用地 & 幹線交通用地 & 幹線交通用地 & $\circ$ & $\circ$ \\
\hline 10 & その他の用地 & その他の用地 & その他の用地 & $\circ$ & - \\
\hline 11 & 湖沼 & \multirow{3}{*}{ 内水池 } & \multirow{3}{*}{ 河川及び湖沼 } & - & - \\
\hline 12 & 河川地 A & & & - & - \\
\hline 13 & 河川地 B & & & - & - \\
\hline 14 & 海浜 & 海浜 & 海浜 & $\circ$ & - \\
\hline 15 & 海水域 & 海水域 & 海水域 & - & - \\
\hline 16 & - & - & ゴルフ場 & $\circ$ & - \\
\hline
\end{tabular}

ことで, 駅勢圈内における自動車分担率を算出し, 駅勢 圈自動車分担率とした. なお，対象駅の駅勢圈同士が重 なる場合も考えられるが，その領域においては複数の対 象駅整備の影響が住民の交通行動に及ぼされ得ると考え られる. そこで駅単位の分析を進める本研究では, 対象 駅整備の影響が及ぶ範囲を $1 \mathrm{~km}$ 圈内(駅勢圈) とした上で, その領域における自動車利用の割合を集計し，駅勢圈同 士の重なりについては考慮しない。

最後に，1970年代整備の対象新駅については1970年， 1980年代整備の対象新駅については1980年，1990年代整 備の対象新駅については1990年における值を, 整備期自 動車分担率として整備年代ごとにデータを整理し, 後述 の類型化に用いる. 2000年および2010年における值は, その経年変化の傾向を確認寸るために用いる.

\section{（3）整備期開発率の算出}

対象新駅の整備期における周辺地域の開発度を表す指 標を算出する.

開発されたと見なすことのできる土地利用を都市的土 地利用とし，式(1)に示すように，その面積が可住地面積 に占める割合を都市的土地利用率とする.

$$
R_{D}=A_{D} / A_{H}
$$

$R_{D}[\%]$ : 都市的土地利用率

$A_{D}[\mathrm{ha}]:$ 都市的土地利用面積

$A_{H}[\mathrm{ha}]$ : 可住地面積

具体的には，国土数值情報の土地利用細分メッシュデ 一タ ${ }^{30}$ における区分を参考に, 表-1に示寸通り, 森林, 河川および湖沼，海水域を表す区分を除く領域を可住地 とし，幹線交通用地，建物用地を示寸区分を都市的土地 
利用とする. そして1976年, 1987年, 1997年の計3年次に ついて，駅勢圈内における可住地面積に対する都市的土 地利用の面積割合を求めることで, 駅勢圈都市的土地利 用率を算出した.

なお，1970年代に整備された新駅については1976年， 1980年代に整備された新駅については1987年，1990年代 に整備された新駅については1997年における值を，整備 期開発率として整備年代ごとにデータを整理した.

\section{(4) 列車運行本数の算出}

次に, 列車運行本数と駅周辺の人口分布との密接な関 連性 31 を踏まえ，本研究では都市鉄道駅の利便性を表す 指標として，列車運行本数を集計する.

2010年10月 1 日段階における対象新駅に発着する上 り・下り方向の運行本数を時刻表 ${ }^{32,33)}$ からカウントし, その平均を取ることで各対象新駅の1日当たり片道運行 本数を算出する.ただし1駅に対して複数路線が同年代に 開業し，かつそれらが直通運転を行っていない場合は， 運行本数の総和を取る.また既に廃止されている5 5 駅につ いては，廃止年次における運行本数を別途算出した.

\section{（5）交通環境負荷およびトリップ特性の推計}

最後に, 都市圈PT調査のマスターデータを用いて, 対 象新駅の周辺地域に居住する住民1人当たりの交通環境 負荷を推計する. 利用したPT調查とその実施年次を表-2 に示寸.都市圈に応じて多少の年次の違いが見られるが, ここでは1970年次, 1980年次, 1990年次, 2000年次, 2010 年次の值として各第1回，各第2回，各第3回，各第4回， 各第5回の調査をそれぞれ用いることにした.

初めに, 日常移動を前提とした分析対象とする有効卜 リップを抽出するため, 森川ら ${ }^{25)}$ の研究を参考に, 以下 の条件を満たすトリップを除外した. この作業により抽 出した有効トリップの総計を表-3に示す.

・「所要時間」「目的」「交通手段」が未記入，その 他および不明とされているトリップ

- 「交通手段」として新幹線, 船舶及び飛行機を含む トリップ

・算出した移動距離の合計が $80 \mathrm{~km}$ 以上，または総所 要時間が240分以上であるトリップ

その後，交通手段別平均旅行速度を算出した。 この指 標は, 対象駅が属している都市圏, 都市圈内における地 域特性，また各トリップを行う時間帯によって大きく変 動すると考えられる，そこで本研究では，各交通手段別 平均旅行速度を都市圈別，市区町村別，時間帯別に算出 した．各分類の一覧とそれらの定義を表-4に示す．ただ し「徒歩」による平均旅行速度は $4.8 \mathrm{~km} / \mathrm{h}$ (分速 $80 \mathrm{~m}$ ) と仮 定した。 なおインフラ整備や技術的進歩により，年代に 応じて平均旅行速度も変化すると考えられるが，交通特
表-2 使用したパーソントリップ調查一覧と各年次

\begin{tabular}{l|c|c|c|c|c}
\hline \multicolumn{1}{c|}{ 調査名/年 } & 第1回 & 第2 回 & 回 & 第4回 & 第 回 \\
\hline $\begin{array}{l}\text { 東京都市圈 } \\
\text { PT 調査 }\end{array}$ & 1968 & 1978 & 1988 & 1998 & 2008 \\
\hline $\begin{array}{l}\text { 中京都市圈 } \\
\text { PT 調査 }\end{array}$ & 1971 & 1981 & 1991 & 2001 & 2011 \\
\hline $\begin{array}{l}\text { 京阪神近畿 } \\
\text { 都市圈 PT 調査 }\end{array}$ & 1970 & 1980 & 1990 & 2000 & 2010 \\
\hline
\end{tabular}

表-3 抽出した有効トリップ数

\begin{tabular}{l|c|c|c|c|c}
\hline 調查名ハリップ & 第1回 & 第2回 & 第3 回 & 第 4 回 & 第 \\
\hline \hline $\begin{array}{l}\text { 東京都市圈 } \\
\text { PT 調査 }\end{array}$ & 773,075 & $1,470,280$ & $1,600,055$ & $2,095,185$ & $1,689,588$ \\
\hline $\begin{array}{l}\text { 中京都市圈 } \\
\text { PT 調査 }\end{array}$ & 545,371 & 772,027 & 589,940 & 676,007 & 531,720 \\
\hline $\begin{array}{l}\text { 京阪神近畿 } \\
\text { 都市圈PT 調査 }\end{array}$ & 717,465 & 847,616 & 856,854 & $1,024,670$ & $2,281,026$ \\
\hline
\end{tabular}

表-4 交通手段別平均旅行速度の分類定義

\begin{tabular}{|c|c|c|c|}
\hline No. & $\begin{array}{c}\text { 大項 } \\
\text { 目 } \\
\end{array}$ & 小項目 & 定義 \\
\hline 1 & \multirow{3}{*}{$\begin{array}{l}\text { 都市 } \\
\text { 圏 }\end{array}$} & 東京都市圏 & 東京都市圏の範囲に属すこと. \\
\hline 2 & & 中京都市圏 & 中京都市圏の範囲に属すこと. \\
\hline 3 & & 京阪神都市圏 & 京阪神都市圏の範囲に属すこと. \\
\hline 4 & \multirow{4}{*}{$\begin{array}{l}\text { 市区 } \\
\text { 町村 }\end{array}$} & 東京 23 区 & 2010 年末の時点で, 東京 23 区に属すこと. \\
\hline 5 & & 政令指定都市 & $\begin{array}{l}2010 \text { 年末の時点で, 政令指定都市の範囲に } \\
\text { 属すこと. }\end{array}$ \\
\hline 6 & & 市 & $\begin{array}{l}2010 \text { 年末の時点で, 政令指定都市を除く市の } \\
\text { 範囲に二属すこと. }\end{array}$ \\
\hline 7 & & 町村 & 2010 年末の時点で, 町村の範囲に属すこと. \\
\hline 8 & \multirow{2}{*}{$\begin{array}{l}\text { 時間 } \\
\text { 帯 }\end{array}$} & ピーク時 & $\begin{array}{l}\text { トリツプの発時間が 7:00-9:00 または } \\
\text { 17:00-20:00に属していること. }\end{array}$ \\
\hline 9 & & オフピーク時 & トリップの発時間がピーク時以外に属すこと. \\
\hline
\end{tabular}

性の変化に着目する本研究では, この経年変化について は考慮しない．また算出の際，中京・京阪神都市圈につ いては，各第5回の都市圈PT調査のマスターデータを用 いるが，東京都市圈については「距離」が集計されてい ないため, 代替として2010年度に行われた全国都市交通 特性調査のマスターデータを別途用いた。

乗用車などの私的交通手段については，公共交通手段 と比較して, 単独トリップが非常に多く含まれる傾向に ある，そこで各トリップから単独トリップを抽出し，式 (2)の通り，「距離」から「所要時間」を除することで交 通手段別平均旅行速度を求めた。

$$
V_{i}^{p r}=L / T_{i}^{p r}
$$

$L[\mathrm{~km}]:$ トリップ距離

$V_{i}^{p r}[\mathrm{~km} / \mathrm{h}]$ : 私的交通手段 $i$ の平均旅行速度

$T_{i}^{p r}[\mathrm{~h}]$ : 私的交通手段 $i の$ 総所要時間

公共交通手段を含むトリップについては基本的に複合 トリップであるため, 初めに, 複数の公共交通手段によ り構成されていないトリップを抽出し, 式(3)より公共交 通手段の平均旅行速度 を算出した. 


$$
V_{i}^{p u} T_{i}^{p u}=L-\sum_{i} V_{i}^{p r} T_{i}^{p r}
$$

$L[\mathrm{~km}]:$ トリップ距離

$V_{i}^{p r}[\mathrm{~km} / \mathrm{h}]$ : 私的交通手段 $i$ の平均旅行速度 $T_{i}^{p r}[\mathrm{~h}]$ : 私的交通手段 $i$ の所要時間

$V_{j}^{p u}[\mathrm{~km} / \mathrm{h}]$ : 公共交通手段 $j$ の平均旅行速度

$T_{j}^{p u}[\mathrm{~h}]$ : 公共交通手段 $j$ の総所要時間

最後に，対象新駅の駅勢圈における交通環境負荷を示 寸指標として，居住地べースの 1 人 1 日当たりの $\mathrm{CO}_{2}$ 排出 量を推計する. 自動車に関しては，道路混雑等を考慮し た推計式 (式(4)・式(5)) ${ }^{34)}$ を用いて, 都市圈別地域別時間 帯別の乗用車速度から単位距離当たりのガソリン消費量 を推計する．ただし，式(4)は「乗用車」および「軽乗用 車」, 式(5)は「普通貨物車」および「軽貨物車」に対し て用いる式である，さらに式(6)より，このガソリン消費 量を単位距離当たりの自動車 $\mathrm{CO}_{2}$ 排出量に換算する。ま た乗用車以外の交通手段については，松橋ら ${ }^{13)}$ の研究を 参考に，単位距離当たりの交通手段別 $\mathrm{CO}_{2}$ 排出量係数を 計算に用いる(表-5). ただし本研究では交通行動の変化 に着眼するために，技術的進歩により想定される係数の 経年変化を考慮せずに，年次によらず一定の係数である と仮定する。

$$
\begin{gathered}
F C=\frac{829.3}{v_{c}}-0.8572 v_{c}+0.007659 v_{c}^{2}+64.09 \\
F C=-\frac{4.178}{v_{c}}-1.974 v_{c}+0.009392 v_{c}^{2}+112.25 \\
E F=E F_{0} \times H V \times F C
\end{gathered}
$$

$F C[\mathrm{cc} / \mathrm{km}]:$ 単位距離当たりガソリン消費量 $E F\left[\mathrm{~g}-\mathrm{CO}_{2} / \mathrm{km}\right]$ : 単位距離当たりの $\mathrm{CO}_{2}$ 排出量 $E F_{0}\left[\mathrm{~g}-\mathrm{CO}_{2} / \mathrm{J}\right]$ : 発熱量当たり $\mathrm{CO}_{2}$ 排出量 $H V[\mathrm{~J} / \mathrm{cc}]$ : 平均発熱量

その後, 式(7)より 1 人 1 日当たりの $\mathrm{CO}_{2}$ 排出量を推計し, ゾーンごとにその平均值を求める.なお,データ制約上, 東京・中京都市圈については計画基本ゾーン, 京阪神都 市圈については小ゾーンを本研究で用いる「ゾーン」と する. また， $\mathrm{CO}_{2}$ 排出量はトリップ目的(通勤，通学，業 務，帰宅，私用・自由)別にも算出寸る.

$$
E F_{\text {ind }}=\sum_{k} T_{k} \times \overline{V_{k}} \times E F_{0}^{k}
$$

$T_{k}[\mathrm{~h}]$ : 交通手段 $k$ を利用した所要時間の合計

$\overline{V_{k}}[\mathrm{~km} / \mathrm{h}]$ : 交通手段 $k$ の都市圈別平均旅行速度

$E F_{\text {ind }}\left[\mathrm{g}-\mathrm{CO}_{2} /\right.$ 人]: $\mathrm{CO}_{2}$ 排出量の推計量

$E F_{0}^{k}\left[\mathrm{~g}-\mathrm{CO}_{2} /\right.$ 人 $\left.\mathrm{km}\right]$ : 交通手段 $k$ の $\mathrm{CO}_{2}$ 排出量原単位

ただし第3回中京都市圈PT調査においては，交通手段
別所要時間が集計対象とされていないため, 総所要時間 と別途求めた代表交通手段別平均旅行速度で代用寸る.

また各ゾーン内において集計されたトリップ数・距離 の合計から，サンプル数の合計を除することで，トリッ プ頻度・距離の平均值もあわせて推計する，なお，トリ ップ距離についてはトリップ目的別にも值を算出する.

最後に面積按分により，対象新駅の駅勢圈における 1 人 1 日当たりの $\mathrm{CO}_{2}$ 排出量とトリップ数・距離の推計值 を算出する。

\section{3. 都市鉄道整備期における自動車分担率と交通 環境負荷の関連性分析}

本章では，整備期自動車分担率，整備期開発率および 列車運行本数により対象新駅を類型化する. その後, こ れらの類型を用いて整備期自動車分担率と交通環境負荷 の関連性を分析し，考察する.

\section{(1) 対象新駅の類型化}

整備期自動車分担率の四分位数を算出し，第 1 四分位 数である $27.63 \%$ と第3四分位数である $14.23 \%$ 基準に, 整備期自動車分担率の上位 $25 \%$ 以上の各駅をグループ 1 「整備期自動車分担率：高」，上位 $25 \%$ から下位 $25 \%$ ま

\begin{tabular}{|c|c|c|}
\hline No. & 交通手段 & $\begin{array}{c}\mathrm{CO}_{2} \text { 排出量原単位 } \\
\left(\mathrm{g}-\mathrm{CO}_{2} / \text { 人 } \mathrm{km}\right)\end{array}$ \\
\hline 1 & 徒歩 & 0 \\
\hline 2 & 自転車 & 0 \\
\hline 3 & 原動機付自転車 & 31 \\
\hline 4 & 自動二輪車 & 92 \\
\hline 5 & タクシー・ハイヤー & 式(4) \\
\hline 6 & 乗用車 & 式(4) \\
\hline 7 & 軽乗用車 & 式(4) \\
\hline 8 & 貨物自動車 & 式(5) \\
\hline 9 & 軽貨物車 & 式(5) \\
\hline 10 & 自家用バス & 50 \\
\hline 11 & 路線バス·路面電車 & 58 \\
\hline 12 & モルール·新交通 & 19 \\
\hline 13 & 鉄道·地下鉄 & 19 \\
\hline
\end{tabular}
での各駅をグループ2「整備期自動車分担率 : 平均」, 下 位 $25 \%$ 未満の各駅をグループ3 整備期自動車分担率: 低」 とした. 類型一覧を表-6に示す.

表-5 $\mathrm{CO}_{2}$ 排出量原単位の一覧 ${ }^{13)}$

表-6 整備期自動車分担率による類型一覧

\begin{tabular}{r|l|r|r|r|r}
\hline No. & \multicolumn{1}{|c|}{$\begin{array}{c}\text { 整備期自動車分担率 } \\
\text { グループ名 }\end{array}$} & $\begin{array}{c}\text { 駅数 } \\
\text { (駅) }\end{array}$ & 上限 & 下限 & 平均值 \\
\hline \hline 1 & 整備期自動車分担率 : 高 & 86 & & $27.63 \%$ & $41.59 \%$ \\
\hline 2 & 整備期自動車分担率 : 平均 & 172 & $27.63 \%$ & $14.23 \%$ & $19.68 \%$ \\
\hline 3 & 整備期自動車分担率 : 低 & 86 & $14.23 \%$ & & $10.84 \%$ \\
\hline
\end{tabular}


整備期開発率の平均值がおよそ $50 \%$ であるとを考慮 して，整備期開発率 $50 \%$ 以上の各駅をグループ a 整備 期開発率：高」，50\%未満の各駅をグループ b 「整備期 開発率 : 低」とした. 類型一覧を表-7 に示寸.

列車運行本数の第 1 四分位数が約 80 本/日(約 4 本 $/ \mathrm{h} の$ 運行本数に相当)であることを考慮して, 列車運行本数 80 本/日以上の各駅をグループ A「運行本数 : 多」, 80 本/日未満の各駅をグループ B「運行本数 : 少」とした. なお，平均值である約 120 本/日(約 6 本/h の運行本数に 相当)を基準とした場合， 80 本未満の低頻度運行の駅か ら, 80 本 120 本の比較的高頻度運行の駅まで含まれ, 整備期自動車分担率と交通環境負荷の関連性を明らかに することができないと予期されたため, 基準として第 1 四分位数(80 本/日)を用いている. 類型一覧を表-8 に示寸. 以上, $3 つ の$ 変数により類型化された各々のグループにお ける整備期自動車分担率, 整備期開発率, 列車運行本数 の平均值を表-9に示す，なお，グループ3-a-Bについては サンプルが確認されず，グループ3-b-Bにおいては1駅の みであるため, 以下の分析ではグループ2-b-Bに統合する.

\section{（2）整備期自動車分担率と交通環境負荷の関連性分析}

はじめに, 各グループの対象駅の分布を都市圈別に図 -1, 図-2 および図-3に示す. 東京都市圈では, グループ 1 に属する対象駅が都心部だけではなく, 東京 23 区周辺 の政令指定都市や郊外都市にも見られる。一方，京阪神 都市圈では, グループ 1 に属する対象駅のほとんどは, 京都市・大阪市・神戸市といった代表都市内にのみに見 られ，代表都市外縁部ではグループ 2 に属する対象駅が 多く確認される。しかし中京都市圈では，代表都市であ る名古屋市中心部においてグループ 1 に属する対象駅は 見られず，都市圈全体ではグループ 3 に属する対象駅が 多くを占めることが分かる. このことから，中京都市圈 における都市鉄道駅整備のタイミングは，モータリゼー ションの進展と比較して遅い傾向にあったことが分かる.

表-7 整備期開発率による類型一覧

\begin{tabular}{c|c|c|c|c|c}
\hline No. & \multicolumn{1}{|c|}{$\begin{array}{c}\text { 整備期開発率 } \\
\text { グループ名 }\end{array}$} & $\begin{array}{c}\text { 駅数 } \\
\text { (駅) }\end{array}$ & 上限 & 下限 & 平均值 \\
\hline \hline $\mathrm{a}$ & 整備期開発率 : 高 & 165 & & $50.0 \%$ & $73.03 \%$ \\
\hline $\mathrm{b}$ & 整備期開発率 : 低 & 179 & $50.0 \%$ & & $29.20 \%$ \\
\hline
\end{tabular}

表-8 列車運行本数による類型一覧

\begin{tabular}{c|l|r|c|c|c}
\hline No. & \multicolumn{1}{|c|}{$\begin{array}{c}\text { 列車運行本数 } \\
\text { グループ名 }\end{array}$} & $\begin{array}{c}\text { 駅数 } \\
\text { (駅) }\end{array}$ & 上限 & 下限 & 平均值 \\
\hline \hline A & 運行本数 $:$ 多 & 262 & & 80 本/日 & 151.8 本/日 \\
\hline B & 運行本数 $:$ 少 & 82 & 80 本/日 & & 49.9 本/日 \\
\hline
\end{tabular}

表-9 本研究における類型一覧

\begin{tabular}{|c|c|c|c|c|c|c|c|}
\hline \multicolumn{5}{|c|}{ 分類一覧 } & \multicolumn{3}{|c|}{ 分類特性 } \\
\hline No. & $\begin{array}{l}\text { 整備期 } \\
\text { 自動車 } \\
\text { 分担率 }\end{array}$ & $\begin{array}{l}\text { 整備期 } \\
\text { 開発率 }\end{array}$ & $\begin{array}{l}\text { 運行 } \\
\text { 本数 }\end{array}$ & $\begin{array}{l}\text { 駅数 } \\
\text { (駅) }\end{array}$ & \begin{tabular}{|c|} 
整備期 \\
自動車 \\
分担率 $(\%)$
\end{tabular} & $\begin{array}{c}\text { 整備期 } \\
\text { 開発率(\%) }\end{array}$ & $\begin{array}{c}\text { 運行本数 } \\
\text { (本) }\end{array}$ \\
\hline 1 & \multirow{4}{*}{ 1. 高 } & \multirow{2}{*}{ a. 高 } & A.多 & $\overline{9}$ & 32.73 & \begin{tabular}{ll|}
70.64 \\
\end{tabular} & 160.0 \\
\hline 2 & & & B.少 & 12 & 41.18 & 65.30 & 53.0 \\
\hline 3 & & \multirow{2}{*}{ b.低 } & A.多 & 20 & 34.88 & 26.07 & 128.4 \\
\hline 4 & & & B.少 & 45 & 46.46 & 26.43 & 48.4 \\
\hline 5 & \multirow{4}{*}{ 2.平均 } & \multirow{2}{*}{ a. 高 } & A.多 & 75 & 19.06 & 74.39 & 152.9 \\
\hline 6 & & & B.少 & 6 & 17.88 & 63.44 & 68.3 \\
\hline 7 & & \multirow{2}{*}{ b.低 } & A.多 & 73 & 19.89 & 30.00 & 146.4 \\
\hline 8 & & & B.少 & 18 & 22.00 & 32.78 & 47.2 \\
\hline 9 & \multirow{4}{*}{ 3.低 } & \multirow{2}{*}{ a. 高 } & A.多 & 63 & 11.18 & 74.12 & 160.9 \\
\hline 10 & & & B.少 & $\underline{0}$ & & & \\
\hline 11 & & \multirow{2}{*}{ b.低 } & A.多 & 22 & 9.97 & 32.88 & 157.8 \\
\hline 12 & & & B.少 & 1 & 8.81 & 13.73 & 17.0 \\
\hline
\end{tabular}

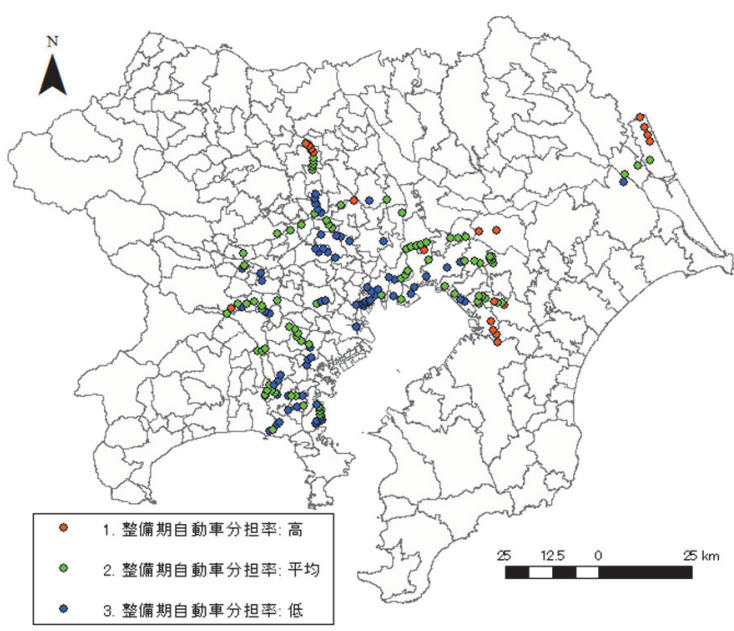

図-1 整備期自動車分担率グループの分布(東京都市圈)

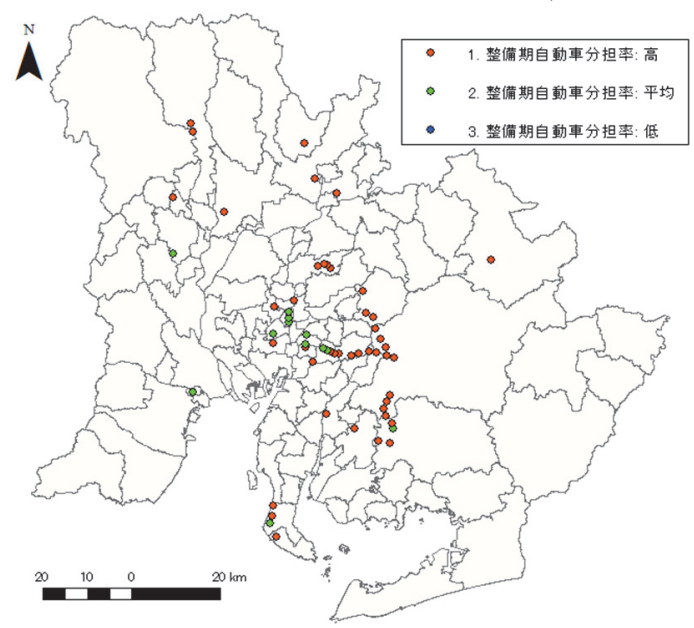

図-2 整備期自動車分担率グループの分布(中京都市圈)

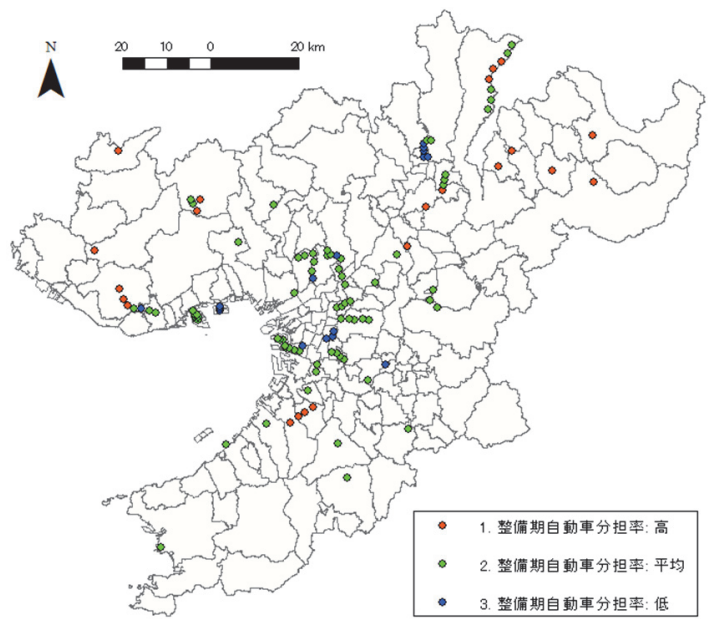

図-3 整備期自動車分担率グループの分布(京阪神都市圈) 
次に，整備期自動車分担率のグループ別に $\mathrm{CO}_{2}$ 排出量 の経年変化量を図-4に示す．また同様に，駅勢圈自動車 分担率と $\mathrm{CO}_{2}$ 排出量の推移を表-10に示す. なお比較対象 として，1970年から2010年の期間に都市鉄道駅の駅勢圈 面積が $0 \mathrm{~km}^{2}$ であったゾーンを鉄道非整備地域と定義し, 図に併記している，ただし同地域では「整備期」を定義 することができないため，整備期における值を1970年， 1980年，1990年の平均值，整備期10年後はこれらの10年 後の年次の平均値, 整備期 20 年後はこれらの 20 年後の年 次の平均值として計算した.

結果として, 整備期自動車分担率が高いグループほど, $\mathrm{CO}_{2}$ 排出量の経年増加量はより大きい傾向にあると分か る. 逆に整備期自動車分担率が低いグループほど, $\mathrm{CO}_{2}$ 排出量の経年増加は抑制されており, 特にグループ3(整 備期自動車分担率 : 低)では20年間で23 g- $\mathrm{CO}_{2}$ の減少傾向 に転じていることが分かる．このグループ間における $\mathrm{CO}_{2}$ 排出量の変化量に見られる傾向は, 駅勢圈自動車分 担率の経年的傾向に合致していることが分かる.

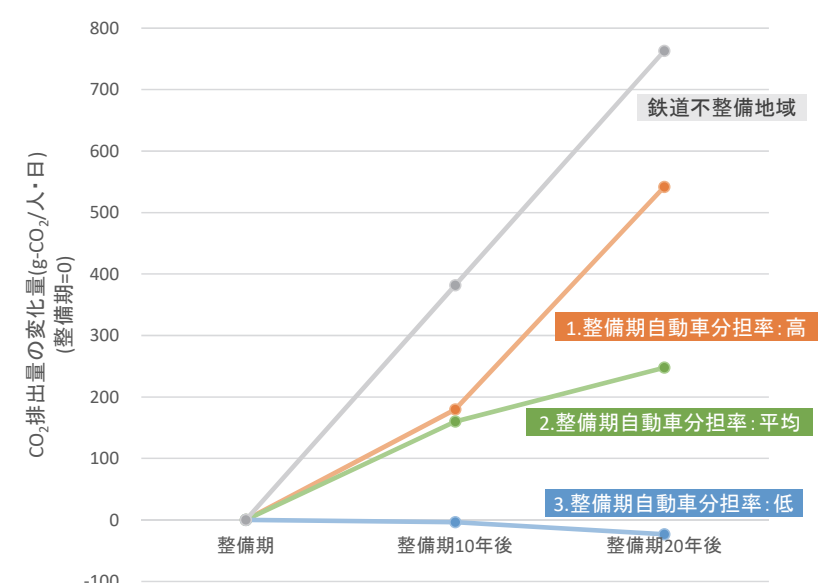

図-4 $\mathrm{CO}_{2}$ 排出量の変化量のグループ間比較

表-10 整備期自動車分担率グループにおける $\mathrm{CO}_{2}$ 排出量と駅 勢圈自動車分担率の推移

\begin{tabular}{|c|c|c|c|c|c|c|c|c|c|}
\hline \multicolumn{2}{|c|}{ 分類 } & \multicolumn{4}{|c|}{ 交通環境負荷 } & \multicolumn{4}{|c|}{ 駅特性 } \\
\hline \multirow{2}{*}{$\begin{array}{l}\text { 整備期 } \\
\text { 自動車 } \\
\text { 分担率 }\end{array}$} & \multirow{2}{*}{ 駅数 } & \multicolumn{4}{|c|}{$\mathrm{CO}_{2}$ 排出量 $\left(\mathrm{g}-\mathrm{CO}_{2} /\right.$ 人·日 $)$} & \multicolumn{4}{|c|}{ 駅勢圏自動車分担率(\%) } \\
\hline & & 整備期 & 10年後 & 20年後 & 変化量 & 整備期 & 10年後 & 20年後 & 変化量 \\
\hline 1.高 & 86 & & 3 & 35 & 542 & & 44.27 & 48 & 6.76 \\
\hline 2.平均 & 172 & & 1,518 & 1,606 & 247 & 19.68 & 20.78 & 21.68 & 2.00 \\
\hline 3.低 & 86 & 1,346 & 1,342 & 1,323 & -23 & 10.84 & 12.59 & 12.35 & 1.51 \\
\hline \multicolumn{2}{|c|}{ 鉄道非整備地域 } & 1,846 & 2,227 & 2,609 & 763 & - & - & - & \\
\hline
\end{tabular}

表-11 整備期自動車分担率グループにおける $\mathrm{CO}_{2}$ 排出量の平 均値の差の検定結果

\begin{tabular}{|c|c|c|c|c|c|c|c|c|c|}
\hline \multirow{3}{*}{$\begin{array}{l}\text { P值 } \\
\text { 整備期 } \\
\text { 動車 } \\
\text { 分担率 }\end{array}$} & \multicolumn{9}{|c|}{ 整備期自動車分担率 } \\
\hline & \multicolumn{3}{|c|}{ 1.高 } & \multicolumn{3}{|c|}{ 2.平均 } & \multicolumn{3}{|c|}{ 3.低 } \\
\hline & 整備期 & 20年後 & 変化量 & 整備期 & 20 年後 & 変化量 & 整備期 & 20年後 & 変化量 \\
\hline 1.高 & - & - & - & $0.0000^{* *}$ & $0.0000^{*}$ & $0,0000^{*}$ & $0,0000^{* *}$ & $0.0000^{* *}$ & $0.0000^{* *}$ \\
\hline 2.平均 & - & - & - & - & - & - & 0.9881 & $0.0000^{* *}$ & $0.0000^{* *}$ \\
\hline 3. 低 & - & - & - & - & - & - & - & - & - \\
\hline
\end{tabular}

さらに，各グループにおける整備期およびその 20 年後 における $\mathrm{CO}_{2}$ 排出量, ならびにその変化量の差が統計的 に有意な差であるかを検証する. 表-11に示すように, 整 備期自動車分担率のグループ間の交通環境負荷の経年変 化量には，統計的に有意な差が見られる．またこの経年 変化に伴い, 整備期には $\mathrm{CO}_{2}$ 排出量の值に有意差が見ら れなかったグループ2とグループ3について, 整備期20年 後には有意な差が見られる.

以上の結果は，都市鉄道駅の整備期において自動車交 通に対する依存度が高い場合には，その駅周辺地域は既 に自動車交通に適した土地利用となっており，対象駅の 整備が駅周辺地域における住民の交通行動に及ぼされ得 る効果が減衰したためであると推察される.このことは, ひとたび自動車中心型都市に陥った地域においては, 都 市鉄道駅整備による交通環境負荷抑制効果は大きく減衰 することを示唆している. しかし整備期自動車分担率の 高いグループ 1 を鉄道非整備地域と比較すると, 20 年間 における $\mathrm{CO}_{2}$ 排出量の増加量は低水準に収まっているた め, 対象駅の整備により交通環境負荷は一定の抑制効果 があると捉えることもできる.

\section{(3) 整備期自動車分担率とトリップ特性の関連性分析}

本節では, 前節の結果を踏まえて, 整備期自動車分担 率とトリップ特性の関連性に着目する.

初めに，整備期自動車分担率グループ別に，トリップ 目的別に推計した $\mathrm{CO}_{2}$ 排出量の経年変化量を図-5に示す. 通学以外のトリップ目的において, 整備期自動車分担率 が高いグループほど， $\mathrm{CO}_{2}$ 排出量はより経年的に上昇す るという傾向を示している，一方で，自動車を運転する ことのできないサンプルが多く含まれると考えられる通 学トリップでは, この傾向は見られない.

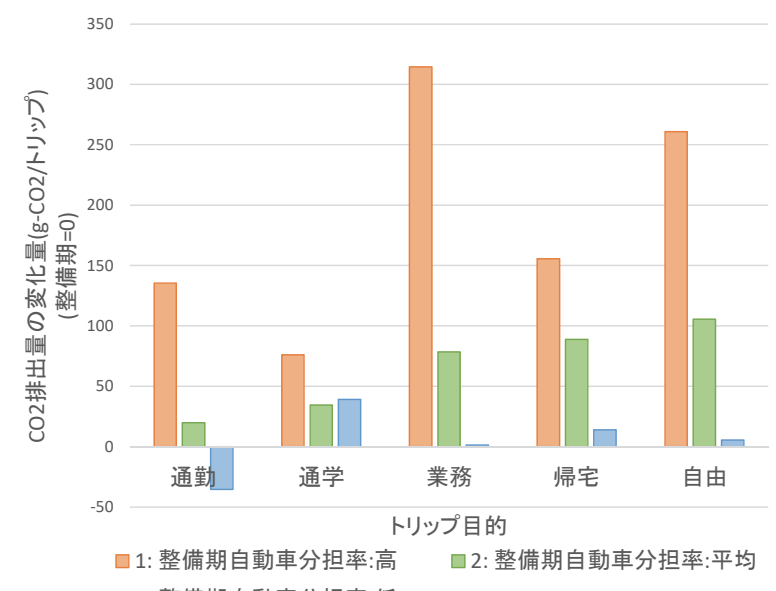

図-5 整備期自動車分担率グルーブにおけるトリップ目的別 $\mathrm{CO}_{2}$ 排出量の変化量のグループ間比較 
また通勤トリップに限り，グループ3(整備期自動車分 担率 : 低)のCO 2 排出量が減少傾向に転じている.このこ とから, 図-4に示したグループ3のCO2排出量の減少傾向 は，通勤トリップにおける経年変化が一因であると分か る. この傾向は, 自動車分担率の低い段階での対象駅の 整備により，駅勢圈内に居住する住民の通勤行動，また 転入者の通勤行動の低炭素化が進んだことを示している. さらに各トリップ目的における, $\mathrm{CO}_{2}$ 排出量の変化量の グループ間差異に着目すると, 業務トリップで最も顕著 であり，グループ1とグループ3の間に1人1日当たり 314 $\mathrm{g}-\mathrm{CO}_{2}(=315 \mathrm{~g}-1 \mathrm{~g})$ の差異が見られる. これは対象駅の整備 によって産業が盛んとなった一方で, その整備期におけ る自動車分担率は高く，業務トリップによる排出量抑制 は困難であったためと推察される.

次に, 整備期自動車分担率グループ別に, トリップ頻 度とトリップ距離(全交通手段)の推移を表-12に示す．整 備期自動車分担率が高いグループほど，トリップ頻度・ 距離ともに，より経年的に上昇するという傾向を示して いる. この傾向は, 整備期自動車分担率の類型間におけ る $\mathrm{CO}_{2}$ 排出量の変化量の差の傾向に対応している. この 経年変化量のグループ間に生じた差異によって，トリッ プ頻度・距離の双方に関して，グループ1とグループ3に おける值の差異が経年的に縮小していることが分かる.

この傾向は, 対象駅の整備およびモータリゼーション の進展に伴って，かつて交通利便性が低かった地域にお いても，次第に高い自動車交通・公共交通双方の利便性 が確保され, 外出機会の増加ならびに住民の交通行動域 の拡大につながったためと考えられる.さらに表-13に示 す通り, 整備期自動車分担率グループ別の自動車交通お よび公共交通のトリップ距離については, 整備期自動車 分担率が高いグループほど, 自動車・公共交通ともにト リップ距離がより増加している.これは, 対象駅の整備 期における自動車交通に対寸る依存度が高い場合，自動 車利用を十分に抑制することができず，住民の生活域が 拡大したために, 自動車・公共交通ともにトリップ距離 が経年増加してきたことを示唆している. またこの結果 から, グループ3での $\mathrm{CO}_{2}$ 排出量の減少傾向は, 通学トリ ップを除いたトリップ目的における，自動車トリップ距 離が縮小したために生じた傾向であることもまた示して いる.

\section{（4）整備期の開発状況を考慮した整備期自動車分担率 と交通環境負荷の関連性分析}

整備期自動車分担率および整備期開発率のグループ別 に, $\mathrm{CO}_{2}$ 排出量の経年変化を図-6および図-7 に示す．ま た同様に, 駅勢圈自動車分担率と $\mathrm{CO}_{2}$ 排出量の推移を表 -14 に示寸.
表-12 整備期自動車分担率グループにおけるトリップ頻度と トリップ距離の推移

\begin{tabular}{|c|c|c|c|c|c|c|c|c|c|}
\hline \multicolumn{2}{|c|}{ 分類 } & \multicolumn{4}{|c|}{ トリップ頻度(トリップ/人) } & \multicolumn{4}{|c|}{ トリップ距離(km/トリップ) } \\
\hline $\begin{array}{l}\text { 整備期 } \\
\text { 自動車 } \\
\text { 分担率 }\end{array}$ & 駅数 & 整備期 & 10年後 & 20年後 & 変化量 & 整備期 & 10年後 & 20年後 & 変化量 \\
\hline 1.高 & 86 & 2.825 & 2.806 & 2.904 & 0.080 & 5.475 & 6.021 & 6.631 & 1.156 \\
\hline 2.平均 & 172 & 2.807 & 2.844 & 2.882 & 0.076 & 6.682 & 7.106 & 7.501 & 0.820 \\
\hline 3. 低 & 86 & 2.891 & 2.891 & 2.893 & 0.002 & 7.211 & 7.209 & 7.754 & 0.543 \\
\hline
\end{tabular}

\begin{tabular}{l|r|r|r|r|r|r|r|r|r}
3. 低 & 86 & 2.891 & 2.891 & 2.893 & 0.002 & 7.211 & 7.209 & 7.754 & 0.543 \\
\hline 鉄道非整備地域 & 2.804 & 2.816 & 2.838 & 0.034 & 5.875 & 6.344 & 6.898 & 1.023 \\
\hline
\end{tabular}

表-13 整備期自動車分担率グループにおける交通手段別トリ ップ距離の推移

\begin{tabular}{|c|c|c|c|c|c|c|c|c|c|}
\hline \multicolumn{2}{|c|}{ 分類 } & \multicolumn{8}{|c|}{ トリップ距離(km) } \\
\hline \multirow{2}{*}{$\begin{array}{l}\text { 整備期 } \\
\text { 自動車 } \\
\text { 分担率 }\end{array}$} & \multirow{2}{*}{ 駅数 } & \multicolumn{4}{|c|}{ 自動車交通 } & \multicolumn{4}{|c|}{ 公共交通 } \\
\hline & & 整備期 & 10年後 & 20 年後 & 変化量 & 整備期 & 10年後 & 20年後 & 変化量 \\
\hline 1.高 & 86 & 6.393 & 6.458 & 6.461 & 0.068 & 13.886 & 16.007 & 18.615 & 4.729 \\
\hline 2.平均 & 172 & 7.499 & 7.601 & 7.478 & -0.021 & 15.486 & 16.635 & 16.627 & 1.141 \\
\hline 3 .低 & 86 & 8.698 & 8.882 & 8.470 & -0.228 & 14.474 & 14.628 & 15.337 & 0.863 \\
\hline 鉄道非整 & 青地域 & 7.023 & 6.892 & 6.854 & -0.169 & 15.163 & 17.767 & 19.991 & 4.828 \\
\hline
\end{tabular}

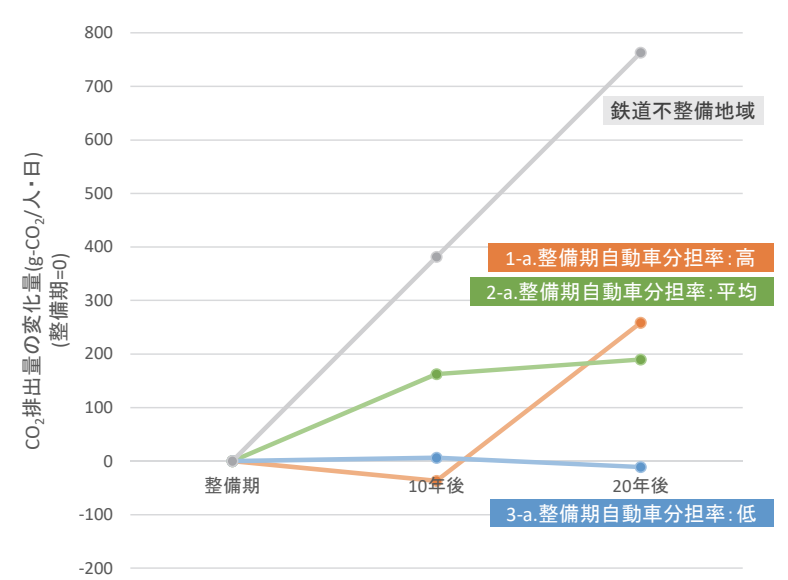

図-6 $\mathrm{CO}_{2}$ 排出量の変化量のグループ間比較 (グループa「整備期開発率 : 高」)

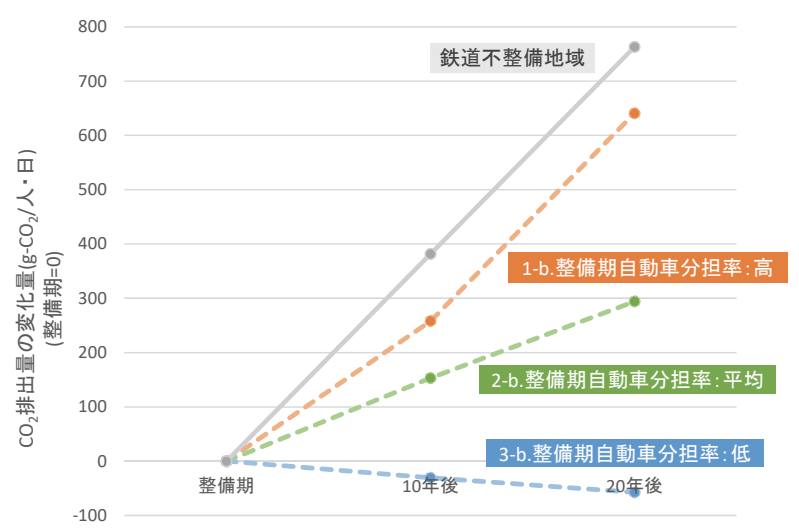

図-7 $\mathrm{CO}_{2}$ 排出量の変化量のグループ間比較 (グループb「整備期開発率 : 低」)

表-14 整備期自動車分担率および整備期開発率グループにお ける $\mathrm{CO}_{2}$ 排出量と駅勢圈自動車分担率の推移

\begin{tabular}{|c|c|c|c|c|c|c|c|c|c|c|}
\hline \multicolumn{3}{|c|}{ 分類 } & \multicolumn{4}{|c|}{$\mathrm{CO}_{2}$ 排出量 $\left(\mathrm{g}-\mathrm{CO}_{2} /\right.$ 人 -日) } & \multicolumn{4}{|c|}{ 駅勢圏自動車分担率 $(\%)$} \\
\hline $\begin{array}{l}\text { 整備期 } \\
\text { 自動 } \\
\text { 分担率 }\end{array}$ & $\begin{array}{c}\text { 整備 } \\
\text { 期 } \\
\text { 開発 } \\
\text { 率 }\end{array}$ & \begin{tabular}{|l} 
駅 \\
数
\end{tabular} & 備期 & 10年後 & 20年後 & 変化量 & 備期 & 10年後 & 20年後 & 変化量 \\
\hline 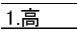 & a.高 & 21 & & & & & & & 79 & 4.23 \\
\hline 平均 & a.高 & 81 & & & & & & & & \\
\hline 3.低 & a. 高 & \begin{tabular}{|l|}
63 \\
\end{tabular} & & 1. & & -1 & 8 & 30 & 62 & 0.45 \\
\hline 1. 高 & b.低 & 65 & & & & & 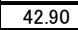 & & 18 & 7.58 \\
\hline${ }^{2}$ & b.低 & 91 & & & & & & & & \\
\hline 3 .低 & b.低 & 23 & 1,440 & 1,409 & 1,382 & -57 & 9.92 & 14.77 & 14.34 & 4.42 \\
\hline 鉄道非 & 整備地 & & 1,846 & 2,227 & 2,609 & 763 & - & - & - & - \\
\hline
\end{tabular}


整備期の開発状況に依らず，整備期自動車分担率が高 いグループほど, $\mathrm{CO}_{2}$ 排出量は経年的による上昇する傾 向にあることが分かる. しかし整備期開発率の高いグル ープ a では, 整備期自動車分担率に応じて排出量に 1 人 1 日当たり $269 \mathrm{~g}-\mathrm{CO}_{2}(=258 \mathrm{~g}-(-11 \mathrm{~g}))$ の差が生じている一 方で, 整備期開発率の低いグループ b では，整備期自動 車分担率に応じてより大きい $698 \mathrm{~g}-\mathrm{CO}_{2}(=641 \mathrm{~g}-(-57 \mathrm{~g}))$ の 差が生じていることが分かる.この傾向は, 自動車分担 率の高まった段階においては開発率の高い地域(図-6), 自動車分担率の低い段階においては開発率の低い地域 (図-7)における都市鉄道整備が，交通環境負荷の抑制傾 向を強めることを示唆している. これは, 整備期開発率 が高い対象駅ほど，駅勢圈は既に都市化の進んだ地域で あり，整備後に一度決まった土地利用が大幅に経年変化 する可能性は低く，それに伴い住民の交通行動を変化さ せることも容易ではないためであると推察される.

次に, 整備期自動車分担率グループ間における, 整備 期および 20 年後の $\mathrm{CO}_{2}$ 排出量, その 20 年間の変化量に 対する多重比較検定の結果を表-15 および表-16 に示す. グループ a (整備期開発率 : 高)については, 整備期にお いて $\mathrm{CO}_{2}$ 排出量の值に有意差が見られるグループ 1 とグ ループ 2 の間を除いて, 整備期自動車分担率グループ間 の交通環境負荷の経年変化量には, 統計的に有意な差が 見られる.またその変化量の差に伴って, 整備期には $\mathrm{CO}_{2}$ 排出量の值に有意差が見られなかったグループ 2 とグル ープ3 について,整備期 20 年後には有意な差が生じてい ることが分かる. 一方で, グループ $\mathrm{b}$ (整備期開発率: 低) については，全ての整備期自動車分担率グループ間にお いて, 交通環境負荷の経年変化量には有意差が見られる. またその変化量の差に伴って, 整備期 20 年後には全ての グループ間に有意な差が生じていることが分かる.

表-15 整備期自動車分担率グループ間における $\mathrm{CO}_{2}$ 排出量の 平均值の差の検定結果(グループ $\mathrm{a}$ 「整備期開発率 : 高」)

\begin{tabular}{|c|c|c|c|c|c|c|c|c|c|}
\hline \multirow{3}{*}{$\begin{array}{l}\text { P值 } \\
\text { 整備期 } \\
\text { 自動車 } \\
\text { 分担率 }\end{array}$} & \multicolumn{9}{|c|}{ 整備期自動車分担率 } \\
\hline & \multicolumn{3}{|c|}{ 1.高 } & \multicolumn{3}{|c|}{ 2.平均 } & \multicolumn{3}{|c|}{3. 低 } \\
\hline & 整備期 & 20年後 & 変化量 & 整備期 & 20年後 & 変化量 & 整備期 & 20年後 & 変化量 \\
\hline 1.高 & - & - & - & $0.0001^{* *}$ & $0.0000^{* *}$ & 0.7703 & $0.0001^{* *}$ & $* 0.0000^{* *}$ & $0.0255^{*}$ \\
\hline 2.平均 & - & - & - & - & - & - & 0.9999 & $0.0151^{*}$ & $0.0106^{*}$ \\
\hline 3. 低 & - & - & - & - & - & - & - & - & - \\
\hline
\end{tabular}

表-16 整備期自動車分担率グループ間における $\mathrm{CO}_{2}$ 排出量の 平均值の差の検定結果(グループb「整備期開発率 : 低」)

\begin{tabular}{|c|c|c|c|c|c|c|c|c|c|}
\hline \multirow{3}{*}{$\begin{array}{l}\text { P值 } \\
\text { 整備期 } \\
\text { 自動車 } \\
\text { 分担率 }\end{array}$} & \multicolumn{9}{|c|}{ 整備期自動車分担率 } \\
\hline & \multicolumn{3}{|c|}{ 1.高 } & \multicolumn{3}{|c|}{ 2.平均 } & \multicolumn{3}{|c|}{ 3.低 } \\
\hline & 整備期 & 20年後 & 変化量 & 整備期 & 20年後 & 変化量 & 整備期 & 20年後 & 変化量 \\
\hline 1.高 & - & - & - & $0.0010^{* *}$ & $0.0000^{*}$ & $0.0029^{* *}$ & 0.0569 & $0.0000^{* *}$ & $0.0000^{*}$ \\
\hline 2.平均 & - & - & - & - & - & - & 0.7851 & $0.0003^{* *}$ & $0.0059^{*}$ \\
\hline 3.低 & - & - & - & - & - & - & - & - & - \\
\hline
\end{tabular}

（5）整備期開発率および列車運行本数を考慮した整備 期自動車分担率と交通環境負荷の関連性分析

整備期自動車分担率および整備期開発率，運行本数の グループ別に， $\mathrm{CO}_{2}$ 排出量の経年変化を図-8～図-11に示 し, 駅勢圈自動車分担率と $\mathrm{CO}_{2}$ 排出量の推移を表-17に示 す.また整備期自動車分担率グループ間における整備期 と20年後における $\mathrm{CO}_{2}$ 排出量, その 20 年間の変化量に対 する多重比較検定の結果を表-18～表-21にそれぞれ示す.

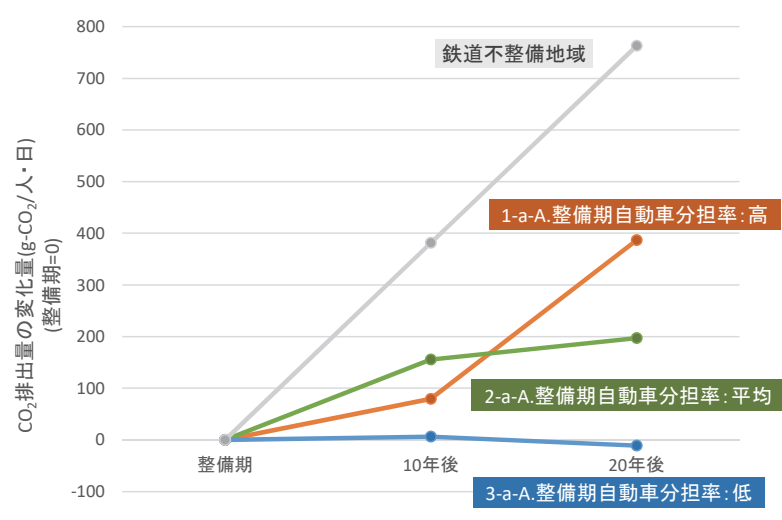

図-8 $\mathrm{CO}_{2}$ 排出量の変化量のグループ間比較 (グループa-A 「整備期開発率 : 高, 運行本数 : 多」)

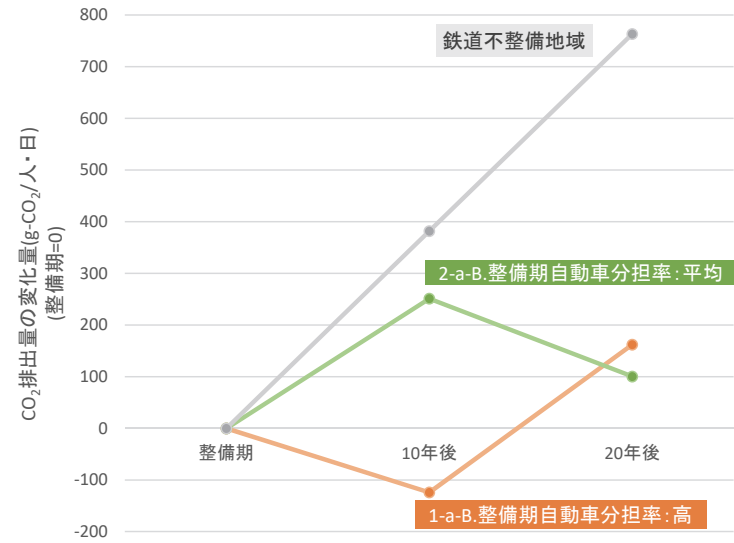

図-9 $\mathrm{CO}_{2}$ 排出量の変化量のグループ間比較 (グループa-B 整備期開発率 : 高, 運行本数 : 少」)

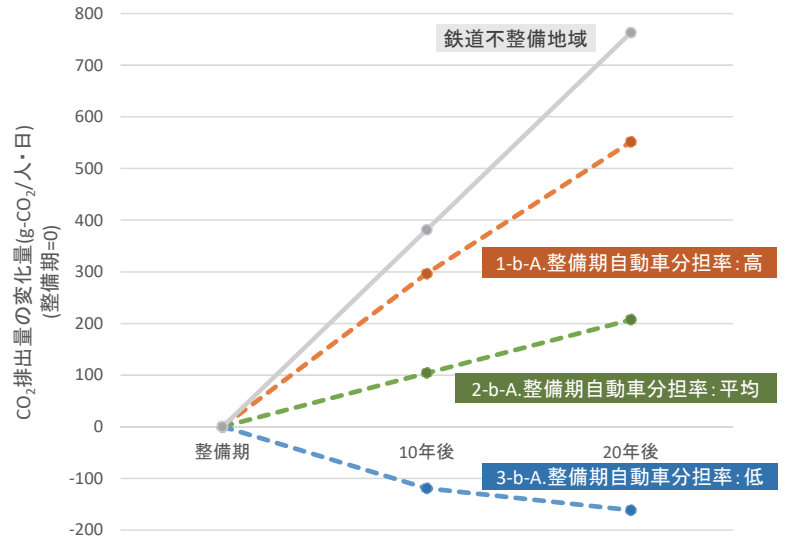

図-10 $\quad \mathrm{CO}_{2}$ 排出量の変化量のグループ間比較(グループb-A 整備期開発率 : 低, 運行本数 : 多」) 


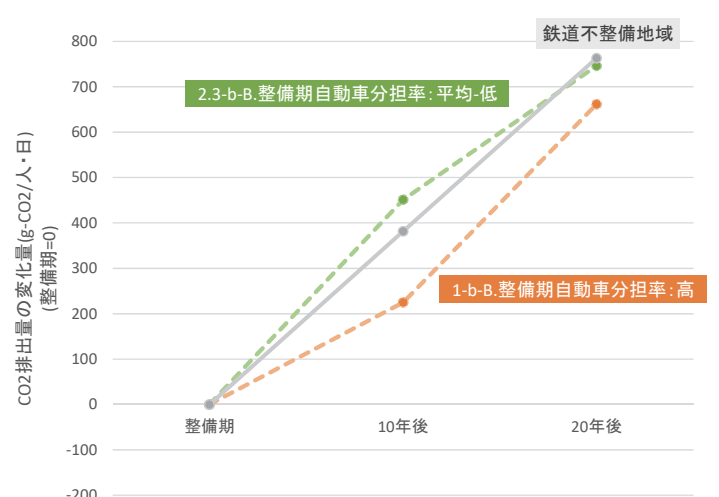

図-11 $\mathrm{CO}_{2}$ 排出量の変化量のグループ間比較(グループ b-B 「整備期開発率 : 低, 運行本数 : 少」)

表-17 全類型における $\mathrm{CO}_{2}$ 排出量と駅勢圈自動車分担率の経 年推移

\begin{tabular}{|c|c|c|c|c|c|c|c|c|c|c|c|}
\hline \multicolumn{4}{|c|}{ 分類 } & \multicolumn{4}{|c|}{$\mathrm{CO}_{2}$ 排出量 $\left(\mathrm{g}-\mathrm{CO}_{2} /\right.$ 人-日) } & \multicolumn{4}{|c|}{ 駅勢圈自動車分担率(\%) } \\
\hline $\begin{array}{l}\text { 整備期 } \\
\text { 䚁分車車公率 }\end{array}$ & & $\begin{array}{l}\text { 運行 } \\
\text { 本数 }\end{array}$ & 駅 & 犕期 & 10 年後 & 20年後 & 変化量 & 整備期 & 10年後 & 年後 & 変化量 \\
\hline & & A. 告 & 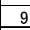 & & 8 & & & 3 & 56 & 8 & \\
\hline 2.平均 & & & 75 & & & & & & & & \\
\hline & 高 & A. 多 & 63 & 1,312 & 18 & & -1 & 1.1 & 11.80 & & \\
\hline & & B. & $\overline{12}$ & & & & & & 33 & & 14 \\
\hline & & & 6 & 1,54 & 1,794 & & & 17.88 & 22.86 & 23.10 & 5.22 \\
\hline & & B.少 & 0 & & & & & . & 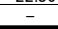 & 20.70 & 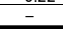 \\
\hline & & A. & 20 & & 0 & & 55 & 8 & 51 & 78 & 5 \\
\hline & b.低 & A. & 73 & & 26 & & & 19.89 & 33 & 5 & -1.34 \\
\hline & b. 低 & A.多 & 22 & & & & & & & & \\
\hline [D] & b. 低 & B.少 & & & & & & & 53.88 & 59.68 & 13. \\
\hline 2-3.平 & b. 低 & B.少 & 19 & 1,302 & 14 & 2,0 & 746 & 21.30 & 32.12 & 39.96 & 18.66 \\
\hline & 翡整備 & & & & 2 & & 76 & & & & \\
\hline
\end{tabular}

表-18 全類型の $\mathrm{CO}_{2}$ 排出量に対する平均值の差の検定結果(グ ループa-A「整備期開発率 : 高, 運行本数 : 多」)

\begin{tabular}{|c|c|c|c|c|c|c|c|c|c|}
\hline \multirow{3}{*}{$\begin{array}{c}\text { P值 } \\
\text { 整備期 } \\
\text { 自動車 } \\
\text { 分担率 }\end{array}$} & \multicolumn{9}{|c|}{ 整備期自動車分担率 } \\
\hline & \multicolumn{3}{|c|}{ 1.高 } & \multicolumn{3}{|c|}{ 2.平均 } & \multicolumn{3}{|c|}{ 3.低 } \\
\hline & 整備期 & 20年後 & 変化量 & 整備期 & 20年後 & 変化量 & 整備期 & 20年後 & 変化量 \\
\hline 1. 高 & - & - & - & 0.0522 & $0.0029^{* *}$ & 0.1452 & 0.0780 & $0.0000^{* *}$ & * $0.0168^{*}$ \\
\hline 2.平均 & - & - & - & - & - & - & 0.9498 & $0.0246^{*}$ & $0.0058^{* *}$ \\
\hline 3.低 & - & - & - & - & - & - & - & - & - \\
\hline
\end{tabular}

表-19 全類型の $\mathrm{CO}_{2}$ 排出量に対する平均値の差の検定結果(グ ループa-B「整備期開発率 : 高, 運行本数 : 少」)

\begin{tabular}{|c|c|c|c|c|c|c|c|c|c|}
\hline \multirow{3}{*}{$\begin{array}{l}\text { P値 } \\
\text { 整備期 } \\
\text { 自動車 } \\
\text { 分担率 }\end{array}$} & \multicolumn{9}{|c|}{ 整備期自動車分担率 } \\
\hline & \multicolumn{3}{|c|}{ 1.高 } & \multicolumn{3}{|c|}{ 2.平均 } & \multicolumn{3}{|c|}{ 3.低 } \\
\hline & 整備期 & 20年後 & 変化量 & 整備期 & 20年後 & 変化量 & 整備期 & 20年後 & 変化量 \\
\hline 1.高 & - & - & - & $0.0491^{* *}$ & $0.0022^{* *}$ & 0.5740 & - & - & - \\
\hline 2.平均 & - & - & - & - & - & - & - & - & 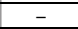 \\
\hline 3.低 & - & - & - & - & - & - & - & - & - \\
\hline
\end{tabular}

表-20 全類型の $\mathrm{CO}_{2}$ 排出量に対する平均值の差の検定結果(グ ループ b-A「整備期開発率 : 低, 運行本数 : 多」)

\begin{tabular}{|c|c|c|c|c|c|c|c|c|c|}
\hline \multirow{3}{*}{$\begin{array}{l}\text { P值 } \\
\text { 整備期 } \\
\text { 自動車 } \\
\text { 分担率 }\end{array}$} & \multicolumn{9}{|c|}{ 整備期自動車分担率 } \\
\hline & \multicolumn{3}{|c|}{ 1.高 } & \multicolumn{3}{|c|}{ 2.平均 } & \multicolumn{3}{|c|}{3. 低 } \\
\hline & 整備期 & 20年後 & 変化量 & 整備期 & 20年後 & 変化量 & 整備期 & 20年後 & 変化量 \\
\hline 1.高 & - & - & - & 0.7227 & 0.0743 & 0.0726 & 0.9494 & $0.0026^{* *}$ & $0.0007^{* *}$ \\
\hline 2.平均 & - & - & - & - & - & - & 0.9115 & $0.0004^{* *}$ & $0.0054^{* *}$ \\
\hline 3. 低 & - & - & - & - & - & - & - & - & - \\
\hline
\end{tabular}

表-21 全類型の $\mathrm{CO}_{2}$ 排出量に対する平均值の差の検定結果(グ ループb-B「整備期開発率 : 低, 運行本数 : 少」)

\begin{tabular}{|c|c|c|c|c|c|c|}
\hline \multirow{2}{*}{ P值 } & \multicolumn{6}{|c|}{ 整備期自動車分担率 } \\
\hline & \multicolumn{3}{|c|}{ 1.高 } & \multicolumn{3}{|c|}{ 2-3.平均-低 } \\
\hline 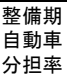 & 整備期 & 20年後 & 変化量 & 整備期 & 20年後 & 変化量 \\
\hline 1.高 & - & - & - & $0.0002^{* *}$ & $0.0366^{*}$ & 0.3528 \\
\hline 2-3.平 & - & - & - & - & - & - \\
\hline
\end{tabular}

グループb-B (整備期開発率 : 低, 運行本数 : 少)を除い て(図-11), 整備期自動車分担率が高いグループほど, $\mathrm{CO}_{2}$ 排出量はより経年的に上昇する傾向にあることが確認さ れる(図-8〜図-10)。また整備期には既に自動車分担率の 高いグループ1とグループ2の間を除いて, 整備期自動車 分担率グループ間において $\mathrm{CO}_{2}$ 排出量の経年変化量に有 意な差が生じており，それに伴って整備期20年後の值に も有意な差が見られる(表-18～表-20)。この傾向は，整 備期における駅勢圈内の開発率が低く, 都市機能が駅周 辺に集積しておらず，かつ対象駅の運行本数が少ないた めに，公共交通を中心に駅周辺地域が発展せず，都市鉄 道駅整備による交通環境負荷の低減効果が大きく減衰し たためであると考えられる．特にグループb-Bにおける $\mathrm{CO}_{2}$ 排出量の変化量については，整備期自動車分担率グ ループ間に有意差(表-21)は見られず，また鉄道非整備地 域の值と大きな差はないことから，対象駅の整備による 住民の交通行動の変化はほとんど生じなかったことを示 しており，また転入者の交通行動も影響として想定され る. またグループa-B(整備期開発率: 高, 運行本数 : 少) においても，整備期自動車分担率に応じた交通環境負荷 の変化量の差異は62 g-CO2 $(=162 \mathrm{~g}-100 \mathrm{~g})$ に過ぎず, 整備期 自動車分担率グループ間に有意差は見られない(表-19). 一方で運行本数の多いグループAでは，ほとんどの整備 期自動車分担率グループ間において， $\mathrm{CO}_{2}$ 排出量の変化 量に有意な差が見られ(表-18および表-20), 都市鉄道駅 の運行本数が交通環境負荷に及ぼす経年的影響は大きい と推察される. この傾向は, 都市鉄道駅の整備により, 人口の集積, 都市鉄道の利用が進み，それにより運行本 数が改善・向上し，さらなる人口の集積，都市鉄道の利 用が進むという正のフィードバックを反映した結果であ ると考えられる。特に整備期自動車分担率が低いほど, $\mathrm{CO}_{2}$ 排出量の抑制傾向が強いことから(図-8および図-10), この正のフィードバックが，自動車分担率の低い段階で の対象駅の整備によって, より強く発生することを示唆 している.

また運行本数の多いグループAに属する整備期自動車 分担率グループ間を確認すると, 整備期開発率の高い駅 のグループa-Aでは, 整備期自動車分担率に応じて排出量 に398 g-CO 2 (=387g-(-11g))の差が生じており, さらに整 備期開発率の低い駅のグループb-Aでは, 整備期自動車 分担率に応じてより大きい714 g-CO $2(=552 \mathrm{~g}-(-162 \mathrm{~g}))$ の 差が生じている. 特に整備期自動車分担率の低いグルー プ3-b-Aにおいては, $\mathrm{CO}_{2}$ 排出量は20年間で162g- $\mathrm{CO}_{2}$ の減 少に転じている. この傾向は, 低未利用地の多い地域の 開発を進める際，整備期自動車分担率が低い段階で利便 性の高い都市鉄道駅を整備することで，都市鉄道駅を中 心に駅勢圈が発展し，人口集積が進んだ際において交通 環境負荷の経年増加を抑制する可能性を示唆している. 


\section{4. 結論}

本研究では，都市鉄道整備期の自動車分担率と整備後 の駅周辺地域における交通環境負荷の経年変化量との関 連性を分析した。

その結果，整備期自動車分担率による類型を用いた分 析では，図-12に示す概念困の通り，整備期自動車分担率 が高い駅ほど，交通環境負荷は経年増加量がより大きい 傾向を統計的に明らかにした。つまり，自動車分担率の 低い段階での都市鉄道整備(早期整備)では，駅周辺地域 における交通環境負荷の抑制傾向は強く，自動車分担率 が高い段階での都市鉄道整備(晚期整備)では，駅周辺地 域における交通環境負荷の増加抑制傾向は弱まることを 示したと言える.この傾向は，自動車分担率，トリップ 頻度・距離の経年変化の傾向と合致することを示した. さらに整備期の開発状況の観点を加えた分析では，自動 車分担率の低い段階では開発率の低い地域，自動車分担 率の高まった段階では開発率の高い地域における都市鉄 道整備が，交通環境負荷の抑制傾向を強めることを示し た.これは，整備期開発率が高い対象駅ほど，駅勢圏は 既に都市化の進んだ地域であり，整備後に土地利用が大 きく変化する可能性は低く，住民の交通行動を変化させ ることは容易ではないためであると推察される.

運行本数が多い類型では，少ない類型と比較して，整 備期自動車分担率に応じて，交通環境負荷の経年増加量 により大きな差異が生じることを明らかにした。この結 果は，都市鉄道駅の列車運行本数が交通環境負荷の抑制 効果に及ぼす経年的影響は非常に大きいことを示唆して いる. 後に，列車運行本数の観点を加えた分析では，列 車運加えて，都市圏の未開発地域における都市開発を進 める際には，整備期自動車分担率が低い段階において利 便性の高い都市鉄道駅を早期整備することが，交通環境 負荷抑制の観点から望ましいことを示した.

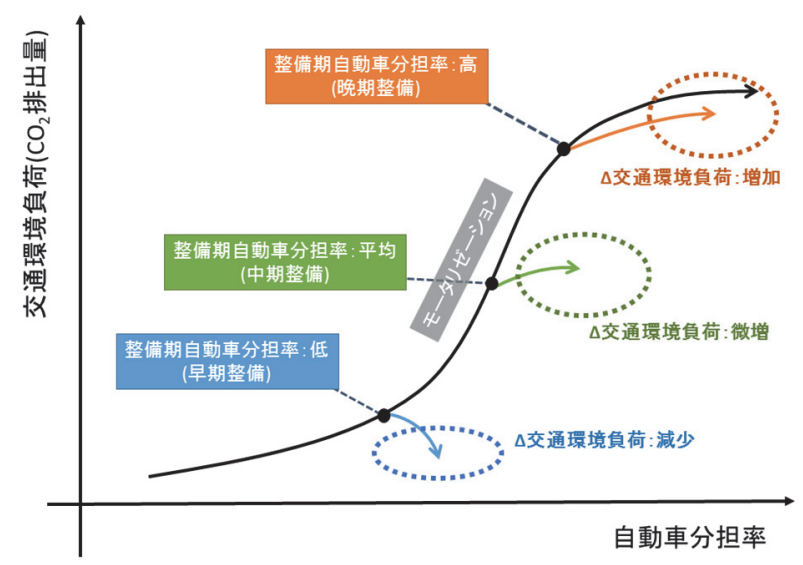

図-12 モータリゼーションに対する都市鉄道整備シナリオ
これらの結果は，自動車分担率の低い段階の地域にお ける都市鉄道整備は，交通環境負荷の抑制傾向が強まる ことを示唆しており，公共交通を中心とした低炭素地域 の構築の見込みは高いことを示している．逆に，モータ リゼーションの進展に伴って発展した自動車依存型都市 から，都市鉄道整備による非自動車依存型の低炭素地域 への再転換の見込みは低い傾向にあることを示唆した. ただし既に自動車分担率の高まった地域においても，開 発率が高い既成都市域では，列車運行本数の多い都市鉄 道駅を整備することで，一定の交通環境負荷の抑制傾向 が得られると考えられる.

以上の考察では，交通特性の経年変化を駅勢圏全体の 変化として捉え，都市鉄道整備期の自動車分担率と交通 環境負荷の経年変化量との関連性を明らかにした。しか しながら，この現象には住民の年齢階層や所得階層とい った住民属性の構成比による影響も考えられる．駅勢圈 内における住民の属性と対象駅の整備期との間に，明確 な関連性が存在するとは考え難いものの，この現象の要 因を明らかにするためには，各対象駅の駅勢圏における 住民属性による影響を考慮する必要性が今後の課題とし て挙げられる.

また本研究では日本の3大都市圈のみを対象としたが, これらに加えて，都市鉄道整備の遅れが既往研究におい て指摘されているアジア途上国の大都市圈を対象地域に 加えることで，都市鉄道整備期と交通行動・交通環境負 荷の経年変化との関連性をより詳細に明らかにすること が可能であると考えられる.

\section{参考文献}

1）加藤博和，林良嗣：巨大都市の爆発的発展と交通シス テム整備の不均衡, 岩波講座地球環境学 第 8 巻「地 球環境と巨大都市」第 4 章, 岩波書店, pp. 81-114, 1998.

2) 北村隆一: 鉄道でまちづくり一豊かな公共領域がつく る賑わい一, 学芸出版社, pp. 92-94, 2004.

3) 島田亮太，加藤博和，林良嗣 : 鉄道整備によるモータ リゼーション進展抑制効果に関寸る基礎的分析, 第 17 回地球環境シンポジウム講演集, pp. 27-31, 2009.

4) 北村隆一：「やさしい」都市交通体系に向けて，都市 問題研究，Vol. 54, No. 12, pp. 30-45, 2002.

5) Acharya, S. R.: Motorization and urban mobility in developing countries exploring policy option through dynamic simulation, Journal of the Eastern Asia Society for Transportation Studies, Vol. 6, pp. 4113-4128, 2005.

6) Morichi, S.: Long-term strategy for transport system in Asian Megacities, Keynote Lecture at the 6th International Conference of EASTS, Bangkok, 2005.

7) Acharya, S. R. and Morichi, S.: Motorization and role of mass rapid transit in East Asian Megacities, IATSS Research, Vol. 31, No. 2, pp. 6-16, 2007.

8) Koizumi, Y., Nishimiya, Y. and Kaneko, M.: Urban transportation characteristics and urban mass transit introduction in the cities of developing countries, Journal 
of the Eastern Asia Society for Transportation Studies, Vol. 10, 2013.

9) Newman, P. and Kenworthy, J.: Sustainability and Cities Overcoming Automobile Dependence, Island Press, Washington, DC., 1999.

10) Glaeser, E. and Kahn, M.: The greenness of cities: carbon dioxide emissions and urban development, NBER Working Paper No. 14238, JEL No. Q5, 2008.

11) Cervero, R.: Public transport and sustainable urbanism: Global lessons, Science Council of Japan, 2006.

12）谷口守，村川威臣，森田哲夫 : 個人行動データを用い た都市特性と自動車利用量の関連分析, 日本都市計画 学会都市計画論文集, pp. 967-972, 1999.

13）松橋啓介, 工藤祐揮, 上岡直見, 森口祐一：市区町村 の運輸部門 $\mathrm{CO}_{2}$ 排出量の推計手法に関する比較研究, 環境システム研究論文集, Vol. 32, 2004.

14）谷口守，松中亮治，平野全宏 : 都市構造からみた自動 車 $\mathrm{CO}_{2}$ 排出量の時系列分析, 日本都市計画学会都市計 画論文集, pp. 121-126, 2008.

15) 鈴木崇正, 室町泰徳 : メガシティを対象とした人口密 度と自動車利用の相互関係に関する再検討一都市面 積と自動車利用距離に注目して一, 日本都市計画学会 都市計画論文集，No. 41-3, pp. 151-156, 2009.

16) Kenworthy, J.: An international review of the significance of rail in developing more sustainable urban transport systems in higher income cities, World Transport Policy and Practice, Vol. 14, No. 2, pp. 21-37, 2008.

17) Choi, H., Nakagawa, D., Matsunaka, D., Oba, T. and Yoon, J.: Estimating the efficiency of transportation energy consumption based on railway infrastructure and travel behavior characteristics, IJR International Journal of Railway, Vol. 6, No. 2, pp. 33-44, 2013.

18）栂達郎, 加藤博和, 林良嗣 : アジア大都市におけるモ ータリゼーション進展仮定を考慮した旅客交通部門 $\mathrm{CO}_{2}$ 排出量の長期予測, 第 18 回地球環境シンポジウ 么講演集, pp. 67-74, 2010.

19) 中村一樹, 加藤博和, 林良嗣 : アジア途上国大都市に おける鉄道整備時期を考慮したモータリゼーション 進展の将来予測, 土木計画学研究・講演集, Vol43, CD-ROM (222), 2011.

20) 中村一樹, 林良嗣, 加藤博和, 福田敦, 中村文彦, 花 岡伸也 : アジア開発途上国都市における低炭素交通シ ステム実現戦略の導出, 土木学会論文集, Vol. 68, No. 5, 2012.

21) Ito, K., Nakamura, K., Kato, H. and Hayashi, H.: Influence of urban railway development timing on long-term car ownership growth in Asian developing mega-cities,
Journal of the Eastern Asia Society for Transportation Studies, Vol. 10, 2013.

22) 北村隆一, 山本俊行, 神尾亮: 高密度都市圈での交通 エネルギー消費削減に向けた土地利用政策の有効性, 土木学会論文集，No. 625/IV-44,pp. 171-180, 1999.

23) 中道久美子, 島岡明生, 谷口守, 松中亮治 : サスティ ナビリティ実現のための自動車依存特性に関する研 究, 日本都市計画学会都市計画論文集, No. 40-3, pp. 37-42, 2005.

24）中道久美子, 谷口守, 松中亮治 : 転居を通じた都市コ ンパクト化による自動車依存低減の可能性，日本都市 計画学会都市計画論文集, No. 43-3, pp. 889-894, 2009.

25）森川達也, 中川大, 松中亮治, 大庭哲治 : 開発時期を 考慮した都市内小地域の空間分類と交通環境負荷と の関連分析, 土木計画学研究・論文集, Vol. 28, pp. 379-387, 2011.

26) 鈴木崇正, 室町泰徳 : 鉄道整備が人口密度と自動車利 用に影響を与える可能性に関する研究, 日本都市計画 学会都市計画論文集, No. 44-3, pp. 73-78, 2009.

27) Mendiola, L., Gonzalez, P. and Cebollada, A.: The link between urban development and the modal split in commuting: The case of Biscay, Journal of Transport Geography, Vol. 27, pp. 1-9, 2014.

28) Travisi, C., Camagni, R. and Nijkamp, P.: Impacts of urban sprawl and commuting: a modelling study for Italy, Journal of Transport Geography, Vol. 18, pp. 382-392, 2010.

29）公益財団法人統計情報研究開発センター: 昭和 45 年・ 昭和 55 年・平成 2 年・平成 12 年・平成 22 年国勢調 査に関する地域メッシュ統計

30）国土数值情報 ダウンロードサービス： http://nlftp.mlit.go.jp/ksj/index.html, 国土交通省国土政 策局国土情報課，2016 年 2 月 26 日閲覧

31) Matsunaka, R., Oba, T., Nakagawa, D., Nagao, M. and Nawrocki, J.: International comparison of the relationship between urban structure and the service level of urban public transportation-A comprehensive analysis in local cities in Japan, France and Germany, Transport Policy, Vol. 30, pp. 26-39, 2013.

32) 日本交通公社 : JTB 時刻表，2010.

33) ヴァル研究所 : 駅すぱあと時刻表, 2010.

34) 谷口守, 池田大一郎, 中野敦 : 都市コンパクト化に配 慮した住宅地整備ガイドラインの構築のための基礎 分析, 土木計画学研究・論文集, Vol. 18, No. 3, pp. 431-437, 2001.

(2016. 2. 26 受付) 


\section{A TIME-SERIES ANALYSIS OF ENVIRONMENTAL IMPACT OF TRANSPORT IN SURROUNDING AREAS OF STATIONS FOCUSING ON PRIVATE VEHICLES DEPENDENCE AT THE TIMING OF URBAN RAILWAY DEVELOPMENT}

\section{Yuma TSUMURA, Ryoji MATSUNAKA, Tetsuharu OBA and Dai NAKAGAWA}

This research aimed to verify the relationship between private vehicles dependence during the development periods of urban railways and the time-series change in environmental impacts of transport; targeting the surrounding areas of new urban railway stations in metropolitan regions of Japan.

The analysis statistically showed that the environmental impact of transport would tend to decrease in areas with lower modal shares of private cars at the timing of urban railway development. On the other hand, it also suggested the rapidly increasing tendency of environmental impact in areas with larger vehicle use at the timing. However, it also revealed that new stations with high frequency departures would contribute to decreasing the environmental impact of transport in highly urbanized areas, even if they are considered auto-dependent. 